Reviews

What he addresses less well is the range of choices that lie before Californians, and the consequences that attend them. The choice is not only about how many people there will be; it is also a choice about who they will be.

People will keep migrating to California; the state is simply too attractive to keep people from entering. On the entire North American continent, only California features the Mediterranean climate to which human civilization has migrated at other locations around the globe for centuries. Add to the mild weather the beauty of the state's mountains and coast, and the hope is dim of getting the rest of America to just stay put in Kansas or Pennsylvania or wherever else Mr. Carle believes they belong.

If people continue to want to move to California, the most likely effect of growth controls will be to bid up the prices of existing homes and land, until folks of modest means give way to the more affluent. This demographic displacement has happened in other attractive places that have enacted growth controls (Boulder, Colorado, for instance, where home prices more than doubled in the first four years after building limits were enacted in 1990). People didn't stop moving in; they just started bidding other people out when they did.

A similar phenomenon can occur even in the absence of growth controls, when new residents arrive at a faster pace than space is made for them. We witnessed this dynamic over and over in the United States during the 20th century, from Manhattan to San Francisco, when demand for places to live outstrips the supply, prices escalate, the wealthy stay, the middle class leave, and a few poor areas remain to house those who serve the rich.

When demand to live in California is unlikely to diminish significantly, much less halt altogether, the question then becomes what to do on the supply side, and with what likely consequences. "Hotel California" may be one nightmare. "Boutique California" is another. Advocates of population limitations (however achieved) must think and proceed carefully--keeping in mind not only how many, but which, Californians shall share the dream.

\title{
Identity and Struggle at the Margins of the Nation State: The Laboring Peoples of Central America and the Hispanic Caribbean, edited by Aviva Chomsky and Aldo Lauria- Santiago. Durham and London: Duke University Press (1998), vi, 404 pp.
}

\author{
Reviewed by Douglas Midgett, Department of Anthropology, University of Iowa.
}

This volume brings together contributions from ten scholars of the labor history of Central America and the Spanish-speaking Caribbean. The editors provide a useful introduction and, in a concluding chapter, Lowell Gudmundson and Francisco A. Scarano discuss directions indicated in the volume for future work. A notable feature of the book is the inclusion of contributors at various stages of their careers. The combination of young scholars, recently embarked on post-graduate endeavors, alongside more senior historians is a felicitous choice and contributes to the over all quality of the book. The timeframe examined extends from 1850, the beginnings of coffee cultivation in the Salvadorian community of Lauria-Santiago's study, to 1944-1954, the revolutionary period of the Guatemalan national history, which ended with the CIA-sponsored coup that brought down the Arbenz regime.

Two recurrent themes are woven through most of the chapters. First, a revisionist argument is played out, with varying degrees of success. In some offerings, Aviva Chomsky's examination of Costa Rican laborers and smallholders, for example, an initial claim that the study argues against conventional interpretations is not supported in the text that follows. The second theme addresses resistance on the part of rural workers in the face of hegemonies rooted in class, race and gender. The second theme is, again, demonstrated with varying effectiveness. The assertion of resistance on the part of the laboring classes is one that I find occasionally tenuous, despite its popularity with academics, especially since the publication of James Scott's Weapons of the Weak (1985). To illustrate the various instances of resistance by the contributors to this volume we are presented with evidence indicated by everything 
Reviews

from verbal insults directed at officials undertaking the expulsions of a peasant family and land squatters on private property (quite obviously an act of resistance), to armed rebellion and the take-over of a sugar factory. If the notion of resistance is to have some explanatory utility for studies of labor history, we need to bring our attention to outcomes that may be produced by such acts, for these are the events that change material conditions.

The book is organized into two sections: a set of seven Central American cases, followed by a second set of three Caribbean cases. There is no examination of the quite significant differences between these two areas, and their inclusion within the same volume would appear to rest on the features of a focus on labor history and Hispanic affiliations. I suggest that the historical determinants of economic adaptations in these two regions are sufficiently different that they at least demand some recognition, if the studies are to be included in the same volume. Individually, the studies demonstrate sound scholarship, and I now turn to a brief survey of each.

Aldo Lauria-Santiago's examination of the ladinoization of Salvadoran peasants is a very localized study, focussing on a single town and its agrarian hinterland. Based on this examination he takes issue with the version of Salvadoran agricultural history that emphasizes the importance of latifundia and the role of the landed elites. LauriaSantiago has assumed a significant revisionist burden for this account of peasant participation in coffee production, but the essay is well researched and persuasive.

Jeffrey Gould discusses the fiction of "disappearance" of Amerindian Nicaraguans and their excision from nationalist accounts of the development of the nation. This is commonplace theme in Latin America where indigenous populations are either marginalized to the status of museum pieces, or absorbed as proletarians -- and thereby become ladinos or mestizos -- into the national society.

Julie Charlip explores the role of credit institutions in the development of the Nicaraguan coffee industry. She meticulously describes the forms of lending that enabled small and medium-sized farmers to avoid displacement by large operators through much of the period between 1870 and 1930 . Having avoided displacement, however, did not prevent emerging disparities where "the larger grower, in his roles of lender, coffee buyer, processor, and exporter, grew wealthy at the expense of the small grower, who kept him supplied with the coffee to market." (p. 118).

The incorporation of peasants within the repressive system in El Salvador after 1880 is the focus of Patricia Alvarenga's chapter. Here the theme of resistance is repeatedly invoked from "daily forms" like "offensive words" to labor desertion, land occupations, and occasional assassinations of the auxiliars civiles, the peasants co-opted to act against their own kind.

The construction of census categories and changing designations over time is the subject of Darío A.

Euraque's essay. He demonstrates the tendency to definitionally reduce ethnic and racial diversity in the effort to construct an image of an emerging Honduran mestizaje. He shows how the black populations of the banana enclaves of the Honduran north coast have been absent from many working-class histories of the country.

Aviva Chomsky's contribution deals with a particularly contentious situation in early 20th century Costa Rica involving the interface between mine owners, laborers, imported Jamaican guards, and smallholders, which eventuated in a massacre of the guards in 1911. She demonstrates that the event can also be read as a rebellion against the (US) mine owners, a fact that has been erased in its historical representation.

Guatemala's revolutionary period of 1944-54 and the role played by campesinos in two areas is the subject of Cindy Forster's paper. She convincingly makes the case that these struggles in a banana-producing township and a coffee-growing area represented proletarian attempts at reconfiguring their working conditions within the general framework of national revolutionary activity. That this subaltern participation is left out of the standard version of the period suggests the elitist bias that grounds historical accounts in these societies.

In the book's first Caribbean case study, Eileen Findlay examines the role of women workers and their location in the labor history of Puerto Rico in the first decades of the century after the Spanish-American War and the assumption of control by the United States. She shows how their activism, marginalized during the struggles in question, becomes little more than a footnote to the historical accounts of the era.

Carr suggests that a focus on alleged feudal aspects of the Cuban sugar industry obscures the "opportunities for maneuver and negotiation that workers could enjoy." p. 281. By this I take him to mean limited possibilities for engaging in subsistence cultivation. Is this resistance? It surely was long a strategy employed by estate owners in the Caribbean who obliged slaves and their successors to be responsible for some of their own means of consumption.

Agrarian programs under the Trujillo regime are the subject of Richard Turits' examination of Dominican agrarian history between 1930 and 1944 . He demonstrates that the basis of Trujillo's rural support rested on land distribution of public lands and private holdings characterized by unclear title. Despite the persuasiveness of his argument, Turits may be overly credulous with respect to government accounts of the situation.

Taken as a whole, a salutary feature of the volume is the attention throughout to avoid the essentializing tendency commonplace in contemporary accounts of multi-ethnic, racialized and gendered social formations. A 
Reviews

useful addition to the volume would have been maps of the various countries and regions under discussion. When attempting an understanding of historical processes that have spatial dimensions, such aids can be most informative.

\title{
References Cited:
}

Scott, James.

1985. Weapons of the Weak: Everyday Forms of Peasant Resistance. New Haven: Yale University Press.

\section{Civil Society and the Political Imagination in Africa, edited by John Comaroff and Jean Comaroff. Chicago: University of Chicago Press. (1999), xi, 318 pp.}

\author{
Reviewed by Edgar V. Winans, Department of Anthropology, University of Washington.
}

In a preface to this volume of essays, the editors remind us of the lively debate about the concept of civil society that has animated some quarters of the intellectual landscape over the past decade and a half. This has been not simply a discussion in the pages of scholarly journals. It engaged many activist intellectuals, especially in the last days of Soviet control over its empire. The question has been not simply of the existence of civil society. There is also discussion of the relevance of civil society to certain forms of state. Some authors have reiterated the longstanding Western view that state power must be balanced by a moral understanding that is embodied in civil institutions. These cannot be mere extensions of a state bureaucratic order, but are voluntary social formations arising out of bonds of common interest and belief. This is the essence of liberal democracy, the very foundations of the liberal state in such a view.

This discussion extends beyond the question of the Soviet Union to consider the post-colonial world more broadly. It is argued by some that Western colonialism, forged in the same timeframe as the liberal state itself, precludes the emergence of the liberal state in its colonial dependencies. These authors maintain that civil society is a consequence of the particularities of Western history and thus has been rendered untenable by the forms of authoritarian centralization practiced in the colonial world. These commentators have therefore found disorder and civil war in the post-colonial world to be a product of the imperfect nature of the successor states. It was in this context that the workshop that gave rise to this volume was convened at the University of Chicago.

Within the rubric of a workshop convened under the Committee on African and African-American Studies at the University of Chicago, the Comaroffs and a group of young colleagues, some still graduate students in 1996 when the discussions began, worked on these issues from the particularity of their individual field experience in a range of African locations. They hailed from several of the social sciences, and brought quite different sorts of understandings to the project. This volume offers closely argued analyses from closely observed circumstances in a number of African countries, mostly Anglophone, but including also Francophone nations. It profits from the differing perspectives the various authors bring from their several disciplines.

In the introduction, the Comaroffs note that while Liberal thought has theorized a distinction between the state and civil society from the time of the Scottish Enlightenment, Jurgen Habermas and his followers gave a new dimension to the distinction through the notion of "communicative action", an idea given form in an era of globalization and the pervasive nature of the media. It is not only through the media that the State seeks to mold its citizens, but may it be also within the media that its critics seek to hold the State accountable and maintain the social values upon which the State forms its policies? Despite the power of these distinctions, there remain serious reservations that the whole mode of thought is Eurocentric and misleading if applied in non-Western contexts.

If the liberal state in Africa is simply an export of Western colonialism that lacks the pluralistic forms of civil society that check its power in the West, then the question arises whether associational forms exist outside the Western tradition which can fulfill this role. The initial formulation does not contemplate this possibility and could be seen as simply an imperialist mode of thought justifying Western action (or inaction) in the global economy.

In the introductory essay by John and Jean Comaroff, and in the nine cases explored by their collaborators, 